\title{
PREGNANCY MANAGEMENT IN PATIENTS WITH ACROMEGALY
}

\author{
LITERATURE REVIEW
}

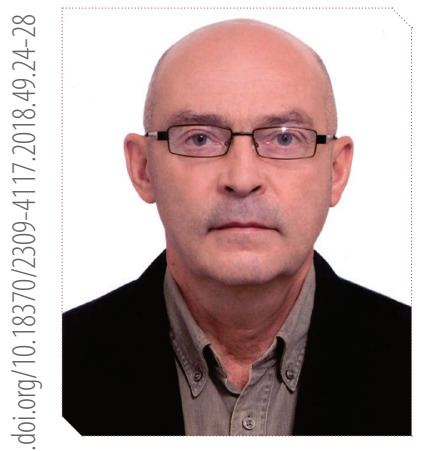

L.B. MARKIN

$M D$, professor, corresponding member of the NAMS of Ukraine, head of the Department of Obstetrics and Gynecology, Danylo Halytsky Lviv National Medical University, Lviv ORCID: 0000-0002-7775-4543

K.L. SHATYLOVYCH

MD, professor of the Department of Obstetrics and Gynecology, Danylo Halytsky Lviv National Medical University, Lviv ORCID: 0000-0002-8465-0355

\section{Contacts:}

Kateryna L. Shatylovych Danylo Halytsky Lviv National Medical University, Department of Obstetrics and Gynecology

79000, Lviv, Rapoporta str., 8 Phone: +38 (067) 7672133 Email:shatik2@ukr.net

\section{INTRODUCTION}

Pregnancy might be accepted as a new physiological state for the pituitary gland with altered anatomy, modified courses, diagnosis, and treatment of pituitary diseases [1]. Due to physiological changes in the pituitary and target hormone levels, binding globulins, and placental hormones, hormonal evaluation becomes more complex in pregnant women. As a consequence of physiological hormonal changes, the evaluation of pituitary functions in pregnant women is quite different from that done in the prepregnant state $[2,3]$.

Acromegaly is a rare, chronic, endocrine disorder, usually caused by hypersecretion of growth hormone (GH) for a prolonged period from a somatotroph adenoma $[4,5]$. The term "acromegaly" is derived from two Greek words: "akrom", meaning extremity, and "megas", meaning great. The meaning reflects one of the familiar symptoms of the disease, which is abnormal growth of hands and feet [6]. Nowadays acromegaly is diagnosed with increasing frequency and its mean age of onset coincides to a great extent with the child-bearing life of women [7].

Treatments currently available for acromegaly include surgery, drug treatment and, in some cases, radiotherapy. These therapeutic modalities achieve tumor growth control and minimize the clinical consequences of hypersomatotropism in most patients [8]. Despite the positive impact of current treatments on survival and quality of life, pregnancy in acromegaly continues to be an uncommon event and a challenge for clinicians.

\section{FERTILITY AND ACROMEGALY}

Infertilily is common in women with acromegaly, as approximately $75 \%$ of acromegalic women of child-bearing years have menstrual irregularities [9]. This is attributed either to anatomic compromise of gonadotropin-producing cells (mass effect in the pituitary) or to concurrent hyperprolactinemia. Prolactin hypersecretion may occur from a mass interfering with dopamine action or from cosecretion along with the $\mathrm{GH}$. In addition, prolactin-like effects of GH (specificity spillover) may contribute to the menstrual irregularity observed in acromegaly $[9,10]$.

Hyperactivity of the somatotropic axis may also alter hormonal cycles leading to ovulation. This, combined with the greater frequency of ovarian functional hyperandrogenism and increased insulin resistance in patients with acromegaly [11], may hinder ovulation and, thus, pregnancy. In addition, hypogonadotropic hypogonadism due to tumor compression or iatrogenic in nature (surgery and radiotherapy) may coexist, and will then require external hormonal induction of ovulation to achieve pregnancy [11, 12].

\section{PHYSIOLOGICAL CHANGES OF PITUITARY GROWTH HORMONE DURING PREGNANCY}

Pregnancy is a state of mild physiological acromegaly $[5,13]$. The number of somatotrophs is reduced in normal pregnancy and basal and stimulated maternal GH levels are suppressed by the second trimester. However, the placenta produces a variant $\mathrm{GH}$ that [14]:

3 differs from pituitary GH by 13 amino acids; - has similar carbohydrate, lipid, and somatogenic properties as pituitary $\mathrm{GH}$, with less lactogenic activity;

binds to hepatic $\mathrm{GH}$ receptor with an affinity that is similar to the affinity with which the receptor binds to $\mathrm{GH}$, and can not be distinguished by conventional radioimmunoassay as different from pituitary $\mathrm{GH}$;

- postpartum disappears from the circulation within 24 hours.

Placental GH is detectable by the fifth week of pregnancy, its levels increase exponentially and peak at 35-37 weeks. The secretion of placental 
$\mathrm{GH}$ is continuous, and regulated neither by $\mathrm{GH}$-releasing factor nor by ghrelin (an enzyme produced by stomach lining cells) [15]. Placental variant of $\mathrm{GH}$ decreases pituitary $\mathrm{GH}$ secretion by insulin-like growth factor-1 (IGF1). The both, placental GH and IGF1, have growth-promoting effects on the fetus and placenta [16]. Decreased GH response to insulin-induced hypoglycemia or arginine suggests decreased reserve of GH secretion by the maternal pituitary (Table 1).

Placenta also produces IGF1 which levels are $[17,18]$ :

dramatically increase in the second half of pregnancy, contributing to the acromegaloid features of some pregnant women;

s suppresses the pituitary secretion of $\mathrm{GH}$ through the normal negative feedback mechanism - pregnancy is a state of physiological GH, IGF1 excess;

are not useful in the diagnosis of acromegaly in pregnancy, as they elevate in the second half of both normal and acromegalic pregnancies;

are normal even in patients with pituitary GH deficiency.

\section{DIAGNOSTICS OF \\ ACROMEGALY IN PREGNANCY}

\section{Biochemical tests}

Diagnosis of new onset acromegaly in pregnancy is problematic due to the complex issue of measuring $\mathrm{GH}$, which includes placental $\mathrm{GH}$ and $\mathrm{GH}$ resistance in the presence of high estrogen. Standard radioimmune evaluation can not distinguish between normal pituitary $\mathrm{GH}$ and the placental variant $\mathrm{GH}$. Because basal levels of placental $\mathrm{GH}$ are high results may erroneously indicate acromegaly. Moreover, in acromegaly pituitary GH secretion are autonomous too so both pituitary and placental GH variants persist throughout pregnancy in a high quantity $[2,19]$.

Also usual reference ranges for both basal and post glucose $\mathrm{GH}$ as well as for IGF1 levels can not be applied to pregnant women, as $\mathrm{GH}$ levels decline and IGF1 levels increase during normal pregnancy [20].

In several researchers clinical activity of acromegaly has been variably shown to improve, remain stable, or worsen during pregnancy, but no clear correlation with hormone levels has been established [7, 23]. In conclusion, hormonal assessment of acromegaly during pregnancy is challenging.

Rarely, acromegaly occurs as a result of ectopic tumors producing $\mathrm{GH}$ or growth hormone-releasing hormone. When a biochemical diagnosis has been established for acromegaly without any pituitary tumor or diffused pituitary enlargement is detected, ectopic sources should be suspected. Measurement of the plasma growth hormone-releasing hormone level is beneficial in identifying ectopic sources of tumor [7].

\section{Imaging studies}

When clinical findings and the limited laboratory examination suggest acromegaly, sella magnetic resonance imaging (MRI) (without gadolinium) is considered to be the most effective imaging technique to locate the pituitary source of excess GH [24]. MRI enables the identification of very small tumors, even smaller than $2 \mathrm{~mm}$, tumor invasiveness, proximity to the optic chiasm, and

Table 1. Summary of characteristics of pituitary and placental $\mathrm{GH}$

\begin{tabular}{|c|c|c|}
\hline Feature & Pituitary GH & Placental GH \\
\hline Source & Somatotroph & Syncytiotrophoblast \\
\hline Maximum levels & Early pregnancy & Late pregnancy \\
\hline Production & Pulsatile (13-19 pulses per $24 \mathrm{~h})$ & Non pulsatile (tonic) \\
\hline Effect of gonadotropin-releasing hormone & Positive & No \\
\hline Paradoxical effect of thyrotropin-releasing hormone & Positive & No \\
\hline Effect of ghrelin & Positive & No \\
\hline Inhibition by glucose & Yes & Yes \\
\hline Response to hypoglycemia & Enhanced & Decreased \\
\hline Response to arginine & Enhanced & Varies \\
\hline IGF1 production & Yes & Yes \\
\hline Measurement by routine tests & Yes & No \\
\hline
\end{tabular}

compression of surrounding structures by the tumor which previously remained undetected. The majority of somatotroph adenomas (75-85\%) are macroadenomas (>10 $\mathrm{mm}$ in diameter) at the time of diagnosis, which rarely grow into the cavernous sinus [25].

Performing computed tomography scans and coned-down views of the sella is not recommended in pregnancy, due to radiation exposure.

\section{CLINICAL COURSE \\ Clinical course of}

\section{acromegaly during pregnancy}

Acromegalic symptoms may improve during pregnancy from the increased estrogen production inhibiting hepatic IGF1 production. Mostly pregnancy has not been found to change the course of acromegaly, other than, in rare cases of asymptomatic tumor enlargement, which may or may not be related to physiologic pituitary hyperplasia [2].

Recurrence of signs and/or symptoms of acromegaly activity occurred in puerperium and were paralleled by increased IGF1 levels. The overall beneficial effect of pregnancy on both clinical and hormonal activity of acromegaly is transient and usually disappears within a few weeks after delivery [26].

In a large retrospective series, only three of 27 cases (11\%) [22] exhibited radiological evidence of tumor growth during pregnancy. Tumor enlargement may also be theoretically triggered by somatostatin receptor ligand discontinuation at pregnancy onset [27]. However, as the pituitary gland enlarges during gestation due to hyperplasia of lactotrophic cells, pregnant patients with macroadenomas may also develop visual symptoms and/or headache as a result of the pituitary enlargement in a restricted sellar space [28].

Tumor enlargement after octreotide withdrawal, tumor apoplexy, aggressive tumors, and untreated acromegaly may determine a less favorable visual outcome during pregnancy [29-31].

The development of gestational diabetes insipidus during late gestation is likely the result from the combined effects of a reduced vasopressin reserve due to previous pituitary surgery and the physiological increase in placental vasopressinase activity in late pregnancy [30, 32]. 
With worsening of the course of acromegaly acromegaly-associated cardiomyopathy may become symptomatic during pregnancy that can be manifested by hypertension, arrhythmias and congestive heart failure. The rest complications associated with acromegaly include sleep breathing disorders, dolichocolon, arthropathies and metabolic disoders [31, 32].

Breast feeding does not affect the course of acromegaly.

\section{Clinical course of pregnancy in women with acromegaly}

The relatively uneventful course of pregnancy and delivery and the healthy newborns is usual. The literature indicates an increased risk of gestational diabetes and gravid hypertension in women with non-controlled GH/IGF1 hypersecretion before gestation [1, 2, 7, 27], which must be appropriately treated, but in most patients, specific acromegaly therapy can be delayed until after delivery.

\section{GH and IGF1 levels during pregnancy}

and puerperium in women with acromegaly

Previous studies showed that in most cases tumor secretion of $\mathrm{GH}$ is autonomous $[2,3,14]$. Thus in pregnant acromegalic patients, pituitary GH levels are initially increased. However, most researches indicate that pregnancy does not further stimulate the secretory activity of somatotrophic adenomas $[19,21,22]$.

Clues to the presence of a true increase in pituitary $\mathrm{GH}$ include a documentation of pulsatility, which is characteristic of acromegaly, while placental GH secretion is apulsatile [19].

The effect of pregnancy on IGF1 levels is likely to reflect the blockade of IGF1 generation by the strikingly high estrogen levels of pregnancy $[34,35]$ which can lead to some improvement in the clinical features of acromegaly during pregnancy [2]. IGF1 levels in patients are increased during the first trimester (as tumoral GH secretion is not progressively suppressed), but remained stable thereafter. The apparent paradox of increasing placental GH with no further increases in IGF1 levels after midgestation in acromegalic patients may reflect that the tumoral GH levels (range 3.7-8.4 mg/l in second trimester) can not be significant to add somatogenic effect to much higher placental GH concentrations (range 2.1-69.8 mg/l in third trimester) in a situation of blunted maximal response of hepatic IGF1 generation $[2,7,14]$.

IGF1 levels increase markedly when the influences of both placental GH and estrogen have completely ceased after delivery $[34,36]$. Thus estrogen-induced $\mathrm{GH}$ resistance is likely to be a major factor keeping IGF1 levels stable in spite of increasing placental $\mathrm{GH}$ and unrestrained tumor $\mathrm{GH}$ secretion during pregnancy $[36,37]$.

\section{Effect of acromegaly on fetus}

$\mathrm{GH}$ does not cross the placenta, and maternal acromegaly has little direct impact on the fetus. While initial reports suggested fetus growth retardation due to hemodynamic changes in materno-fetal barrier, further studies failed to confirm an association with small babies for gestational age and suggested no apparent adverse effects [8, 20, 23].

Macrosomia in such pregnancies is likely secondary to maternal glucose intolerance [20].

\section{ACROMEGALY THERAPY}

Somatostatin analogs, dopamine agonists and $\mathrm{GH}$ receptor ligands are used in acromegaly. Pharmacological treatment with somatostatin analogs has been associated with decreased length in newborns and small-for-gestational-age babies [16, 39]. Nevertheless, octreotide, a short-acting somatostatin analog, can be successfully used to treat tumor enlargement symptoms (has a dramatic analgesic effect on acromegaly-associated headache) [41, 42].

Initial reports on the use of pegvisomant (GH receptor antagonist) in pregnancy have been encouraging, but data are insufficient to support the usage of this agent in anything but an exceptional situation [38]. No transfer across the placenta or entering of the breast milk has been noted. Because of the lack of many case reports and no controlled studies, this agent is best avoided during pregnancy other than in clinically indicated situations.

Use of dopamine agonists (cabergoline, bromocriptine) during pregnancy in some cases has been associated with fetal macrosomia [21]; otherwise use of these drugs throughout pregnancy has not been associated with any fetal malformation or any adverse postnatal development [40]. In patients with significant tumor enlargement during pregnancy or with severely symptomatic acromegaly, bromocriptine therapy or transsphenoidal surgery is an appropriate treatment option.

A Practice Guideline on Acromegaly by the US Endocrine Society (2014) included the following recommendations on pregnancy:

In pregnancy long-acting somatostatin receptor ligands formulations and pegvisomant should be discontinued approximately 2 months before attempts to conceive, with use of short-acting octreotide as necessary until conception [43].

- Dopamine agonists (bromocriptine or cabergoline) or somatostatin analogs (octreotide or lanreotide) can be instituted in patients with symptomatic (headache) tumor enlargement during pregnancy or with severely symptomatic acromegaly [44]. - Transsphenoidal surgery can be performed during the second trimester if there is no relief [45].

Women with tumor expansion during pregnancy should be advised against breast feeding [6].

Drugs for acromegaly therapy in pregnant women presented at Table 2.

\section{PREGNANCY MANAGEMENT}

\section{IN ACROMEGALIC PATIENTS}

Optimal management of acromegaly during pregnancy has not been established. With the widespread use of pharmacological treatment to control disease activity, a consensus on acromegaly management has recently stated the need to encourage reporting of outcomes in medically treated pregnant patients.

Thus an analysis of the literature $[6,16,22,23,33]$ and our own clinical experience have allowed to include the following recommendations for pregnancy management in acromegalic patients: 3 Discontinue long-acting somatostatin receptor ligands formulations and pegvisomant approximately 8 weeks before conception, with use of short-acting octreotide.

- Acromegaly medical therapy should be withheld and administered only for tumor growth and headache control during pregnancy. 
Table 2. Drugs for acromegaly therapy in pregnant women

Drug

Bromocriptine

(dopamine agonists) Category B*

Cabergoline

(dopamine agonists) Category B*

Octreotide

(somatostatin analogs) Category B*

Lanreotide

(somatostatin analogs) Category C*
Dosage

$2.5-20 \mathrm{mg}$ orally two times per day.

$0.5 \mathrm{mg}$ orally two times per week.

20 mg subcutaneously every 4 weeks for 3 months; titrate up or down to 10-30 mg; not to exceed $40 \mathrm{mg}$.

60-90 mg subcutaneously every 4 weeks for 3 months; not to exceed $120 \mathrm{mg}$.
Comments

Cross the human placenta.

Maternal and fetal prolactine levels are suppressed

Second-line therapy.

Useful in women who are resistant or can not tolerate bromocriptine.

Risk of fetal growth retardation.

Risk of fetal growth retardation.

Decreased fetal survival and increased fetal skeletal/soft tissue abnormalities (in rats).

* U.S. Food and Drug Administration pregnancy categories

Monitoring of GH and/or IGF1 levels during pregnancy is not necessary in patients without clinical symptoms.

- Clinical and biochemical evaluation at least one time per trimester and at least one time after delivery (between 3 and 6 weeks) in patients with registered symptoms.

Screening for diabetes mellitus between 24 and 28 weeks.

Screening for pregnancy-induced hypertension.

- Visual field testing monthly in women with macroadenoma, in women with microadenoma every 3 months.

- Sellar MRI without contrast can be performed after the first trimester in case of symptoms and visual field abnormalities.

- Lactation is allowed except for women with tumor expansion during pregnancy.

- The decision to resume drug treatment and stop lactation should be individualized according to clinical judgment.

\section{REFERENCES/ЛІTЕРАТУРА}

1. Karaca, Z., Tanriverdi, F., Unluhizarci, K., et al.

"Pregnancy and pituitary disorders." Eur J Endocrinol 162 (2010):

453-75. DOl: 10.1530/EJE-09-0923

2. Dias, M.L., Vieira, J.G., Abucham, J.

"Detecting and solving the interference of pregnancy serum, in a

GH immunometric assay." Growth Hormone IGF Research 23 (2013)

13-8. D0l: 10.1016/j.ghir.2012.11.001

3. Feldt-Rasmussen, U., Mathiesen, E.R.

"Endocrine disorders in pregnancy: physiological and hormonal

aspects of pregnancy. Best Practice \& Research." Clinical Endocrinology

\& Metabolism 25 (2011): 875-84. D0l: 10.1016/.beem.2011.07.004

4. Petersenn, S., Christ-Crain, M., Droste, M., et al.

"Pituitary Disease in Pregnancy: Special Aspects of Diagnosis and

Treatment?" Geburtshilfe Frauenheilkd Apr 79.4 (2019): 365-74.

DOl: $10.1055 / \mathrm{a}-0794-7587$

5. Cheng, V. Faiman, C. Kennedy, L., et al.

"Pregnancy and acromegaly: a review."Pituitary 15 (2012): 59-63.

DOI: 10.1007/s11102-011-0330-3

6. Katznelson, L., Laws, E.R. Jr., Melmed, S., et al.

"Acromegaly: an endocrine society clinical practice guideline." I Clin

Endocrinol Metab 99 (2014): 3933-51. D0l: 10.1210/jc.2014-2700

7. Al Dallal, S.

"Acromegaly: a challenging condition to diagnose."International Journal of General Medicine 11 (2018): 337-43. DOI: 10.2147/IJGM.S169611

8. Fleseriu, M.

"Medical treatment of acromegaly in pregnancy, highlights on new

reports." Endocrine 49 (2015): 577-9.

DOl: $10.1007 / s 12020-015-0603-0$

9. Kaltsas, G., Androulakis, I., Tziveriotis, K., et al.

"Polycystic ovaries and the polycystic ovary syndrome phenotype in women with active acromegaly." Clin Endocrinol 67 (2007): 917-22. DO|: 10.1111/i.1365-2265.2007.02987

10. Lebbe, M., Hubinont, C., Bernard, P., et al.

"Outcome of 100 pregnancies initiated under treatment with

cabergoline in hyperprolactinaemic women." "Clin Endocrinol 73

(2010): 236-42. DOI: 10.1111/j.1365-2265.2010
11. Grynberg, M., Salenave, S., Young, J., et al.

"Female gonadal function before and after treatment of acromegaly." Journal of Clinical Endocrinology and Metabolism 95 (2010):

4518-25. DOI: 10.1210/jc.2009-2815

12. Маркін, Л.Б.

Профілактика невиношування вагітності після індукції овуляції у жінок з ендокринним неплідлям в анамнезі / Л.Б. Маркін,

К.Л. Шатилович, Г.Б. Семенина // Запорожский медицинский

журнал. - 2019. - № 21 (4). - С. 484-490.

Markin, L.B., Shatylovych, K.L., Semenyna, G.B.

"Prevention of miscarriage after induction of ovulation in women with

a history of endocrine infertility." Zaporizhzhya medical journal 21.4

(2019): 484-90. DOl: 10.14739/2310-1210.2019.4.173345

13. Laway, B.A., Mir, S.A.

"Pregnancy and pituitary disorders: Challenges in diagnosis and management." Indian J Endocrinol Metab 17.6 (2013): 996-1004

DOl: $10.4103 / 2230-8210.122608$

14. Frankenne, F., Closset, J., Gomez, F., et al.

"The physiology of growth hormones (GHs) in pregnant women and partial characterization of the placental GH variant." J Clin Endocrino

Metab 66 (1988): 1171-80. D0I: 10.1210/jcem-66-6-1171

15. Feldt-Rasmussen, U., Mathiesen, E.R.

"Endocrine disorders in pregnancy: Physiological and hormonal aspects of pregnancy." Best Pract Res Clin Endocrinol Metab 25 (2011):

875-84. D01: 10.1016/j.beem.2011.07.004

16. Laway, B.

"Pregnancy in acromegaly."Therapeutic advances in endocrinology and metabolism 6.6 (2015): 1-6. DOI: 10.1177/2042018815603927

17. Velegrakis, A., Sfakiotaki, M., Sifakis, S.

"Human placental growth hormone in normal and abnormal fetal growth." Biomed Rep 7.2 (2017): 115-22. D0l: 10.3892/br.2017.930

18. Shimatsu, A. Usui, T., Tagami, T., et al.

"Suppressed levels of growth hormone and insulin-like growth factor-1 during successful pregnancy in persistent acromegaly." Endocrine Journal 57 (2010): 551-3. D0l: 10.1507/endocri.K10E-069

19. Beckers, A., Stevenaert, A., Foidart, J.M., et al.

"Placental and pituitary growth hormone secretion during pregnancy

in acromegalic women." Journal of Clinical Endocrinology and

Metabolism 71 (1990): 725-31. D0l: 10.1210/jcem-71-3-725
20. Dias, M.., Boguszewski, C., Gadelha, M., et al.

"Acromegaly and pregnancy: a prospective study." European Journal of Endocrinology 170 (2014): 301-10. D0l: 10.1530/EJE-13-046

21. Cheng, S., Grasso, L., Martinez-Orozco, J.A., et al.

"Pregnancy in acromegaly: experience from two referral

centers and systematic review of the literature." Clinical Endocrinology 76 (2012): 264-71. D0l: 10.1111/j.1365-2265.2011.04180

22. Caron, P., Broussaud, S., Bertherat, J., et al.

"Acromegaly and pregnancy: a retrospective multicenter study of

59 pregnancies in 46 women." Journal of Clinical Endocrinology and

Metabolism 95 (2010): 4680-7. D0I: 10.1210/jc. 2009-2331

23. Laway, B.A.

"Pregnancy in acromegaly."Ther Adv Endocrinol Metab 6.6 (2015):

267-72. DO|: 10.1177/2042018815603927

24. Famini, P., Maya, M.M., Melmed, S.

"Pituitary Magnetic Resonance Imaging for Sellar and Parasellar Masses: Ten-Year Experience in 2598 Patients." J Clin Endocrinol Metab 96.6 (2011): 1633-41. D0|: 10.1210/jc.2011-0168

25. Tosaka, M., Higuchi, T., Horiguchi, K.

"Preoperative Evaluation of Sellar and Parasellar Macrolesions by [ ${ }^{18 \mathrm{~F}}$ Fluorodeoxyglucose Positron Emission Tomography."World Neurosurg 103 (2017): 591-9. D0I: 10.1016/j.wneu.2017.04.032

26. Lau, S.L., McGrath, S., Evain-Brion, D., et al.

"Clinical and biochemical improvement in acromegaly during

pregnancy."J of Endocrin Invest 31 (2008): 255-61.

DOl: $10.1007 / B F 03345599$

27. Caron, C., Buscail, L., Beckers, A., et al. "Expression of somatostatin receptor SST4 in human placenta and absence of octreotide effect on human placental growth hormone concentration during pregnancy."The Journal of Clinical Endocrinology \& Metabolism 82.11 (1997): 3771-6. D0l: 10.1210/jcem.82.11.4350 28. Araujo, P.B. Neto, L.V., Gadelha, M.R.

"Pituitary Tumor Management in Pregnancy." Endocrinol Metab Clin North Am 44 (2015): 181-97. D0l: 10.1016/.ecl.2014.10.015

29. Melmed, S., Casanueva, F.F., Klibanski, A., et al.

"A consensus on the diagnosis and treatment of acromegaly complications." Pituitary 16 (2012): 294-302.

DOl: $10.1007 / 511102-012-0420-x$ 


\section{ЕНДОКРИНОЛОГІЯ}

30. Ramirez, C., Vargas, G., Gonzalez, B.

"Discontinuation of octreotide LAR after long term, successful treatment of patients with acromegaly: is it worth trying?"E European Journal of

Endocrinology 166 (2012): 21-6. DOI: 10.1530/EJE-11-0738

31. Kasuki, L., Neto, L.V., Takiya, C.M., et al.

"Growth of an aggressive tumor during pregnancy in an acromegalic patient" Endocrine Journal 59 (2012): 313-9. D0l: 10.1507/endocri.EJ11-0306

32. Adelman, D.T., Liebert, K.J., Nachtigall, L.B., et al.

"Acromegaly: the disease, its impact on patients, and managing the

burden of long-term treatment." Int J Gen Med 6 (2013): 31-8.

DOI: $10.2147 /$ IJGM.S38594

33. Abreu, A, Tovar, A.P., Castellanos, R., et al.

"Challenges in the diagnosis and management of acromegaly: a focus on comorbidities." Pituitary 19.4 (2016): 448-57.

DOI: 10.1007/s11102-016-0725-2

34. Leung, K.C., Johannsson, G., Leong, G.M., et al.

"Estrogen regulation of growth hormone action." Endocrine Reviews

25.5 (2004): 693-721. D0l: 10.1210/er.2003-0035

35. Shimon, I., Barkan, A.

"Estrogen treatment for acromegaly." Pituitary 15 (2012): 601-7. DOl:

$10.1007 / 511102-012-0426-4$
36. Clemmons, D.R.

"Consensus statement on the standardization and evaluation of growth hormone and insulin-like growth factor assays." Clin Chem 57.4 (2011): 555-9. D0l: 10.1373/clinchem.2010.150631

\section{Rosario, P.W., Calsolari, M.R.}

"Laboratory investigation of acromegaly: Is basal or random $\mathrm{GH}>0.4$ $\mu \mathrm{g} / \mathrm{L}$ in the presence of normal serum IGF1 an important result?" Arch Endocrinol Metab 59.1 (2015): 54-8.

DOl: $10.1590 / 2359-3997000000010$

38. Van der Lely, A.J., Gomez, R., Heissler, J.F., et al.

"Pregnancy in acromegaly patients treated with pegvisomant."

Endocrine 49.3 (2014): 769-73. D0l: 10.1007/s12020-014-0508-3

39. Paragliola, R.M., Salvatori, R.

"Novel Somatostatin Receptor Ligands Therapies for Acromegaly."

Front Endocrinol (Lausanne) 7.9 (2018): 78.

DOI: $10.3389 /$ fendo.2018.00078

40. Colao, A., Abs, R., Barcena, D.G., et al.

"Pregnancy outcomes following cabergoline treatment: extended

results from a 12-year observational study." (linical Endocrinology 68

(2008): 66-71. D0l: 10.1111/j.1365-2265.2007.03000.x
41. Colao, A. Auriemma, R.S., Pivonello, R.

"The effects of somatostatin analogue therapy on pituitary tumor volume in patients with acromegaly." Pituitary 19.2 (2016): 210-21.

DOI: 10.1007/s11102-015-0677-y

42. Paragliola, R.M., Corsello, S.M., Salvatori, R.

"Somatostatin receptor ligands in acromegaly: clinical response and factors predicting resistance." Pituitary 20.1 (2017): 109-15.

DOl: $10.1007 / 511102-016-0768-4$

43. Anthony, L., Freda, P.U.

"From somatostatin to octreotide LAR: evolution of a somatostatin analogue." Curr Med Res Opin 25.12 (2009): 2989-99.

DOl: $10.1185 / 03007990903328959$

44. Cuevas-Ramos, D., Fleseriu, M.

"Somatostatin receptor ligands and resistance to treatment in pituitary adenomas." J Mol Endocrinol 52.3 (2014): 223-40.

DOl: 10.1530/JME-14-0011

45. Starke, R.M., Raper, D.M., Payne, S.C., et al.

"Endoscopic vs microsurgical transsphenoidal surgery for acromegaly: outcomes in a concurrent series of patients using modern criteria for remission."J Clin Endocrinol Metab 98.8 (2013): 3190-8.

DOl: 10.1210/j.2013-1036

\section{PREGNANCY MANAGEMENT IN PATIENTS WITH ACROMEGALY}

\section{Literature review}

L.B. Markin, MD, professor, corresponding member of the NAMS of Ukraine, head of the Department of Obstetrics and Gynecology, Danylo Halytsky Lviv National Medical University, Lviv K.L. Shatylovych, MD, professor of the Department of Obstetrics and Gynecology, Danylo Halytsky Lviv National Medical University, Lviv Acromegaly is a rare, chronic, endocrine disorder, usually caused by hypersecretion of growth hormone (GH) for a prolonged period from a somatotroph adenoma. Hormonal evaluation becomes more complex in pregnant women due to physiological changes in the pituitary and target hormone levels, binding globulins, and placental hormones. Evaluation of pituitary functions in pregnant women is quite different from nonpregnant women because of physiological hormonal changes. Pregnancy in acromegaly continues to be an uncommon event and a challenge for clinicians despite the positive impact of current treatments on survival and quality of life. Diagnosis of acromegaly during pregnancy is difficult because of changes in GH and insulin like growth factor 1 (IGF 1 ) levels, GH production by placenta, and the inability of routine methods to distinguish the pituitary GH from placental GH.

In the majority of patients with acromegaly pregnancy does not have an adverse effect on mother or fetus and pituitary mass does not increase in size. Tumor enlargement may theoretically occur if pre-existing therapies such as somatostatin analogues are discontinued with the onset of pregnancy. Acromegalic symptoms may improve during pregnancy, possibly from the increased estrogen production inhibiting hepatic IGF 1 production. Pregnancy course is mostly uneventful but the literature indicates an increased risk of gestational diabetes and gravid hypertension in women with non-controlled GH/IGF 1 hypersecretion before gestation.

In case of tumor enlargement frequent monitoring is required, surgery can be considered in the second trimester. Dopamine agonists and somatostatin analogs can be used without any adverse consequences on mother or fetus. In pregnancy acromegaly medical therapy should be withheld and administered only for tumor growth and headache control during pregnancy. Breast feeding does not affect the course of acromegaly. Postpartum pituitary imaging demonstrates no increased tumor growth after pregnancy.

Keywords: acromegaly, pregnancy, growth hormone, insulin like growth factor-1, dopamine agonists, somatostatin analogs.

\section{ВЕДЕННЯ ВАГІТНОСТІ В ПАЦІЕНТОК ВЗ АКРОМЕГАЛІЕЮ}

\section{Огляд літератури}

Л.Б. Маркін, д. мед. Н., професор, член-кореспондент НАМН України, завідувач кафедрою акушерства та гінекології Львівського національного медичного університету ім. Данила Галицького, м. Львів К.Л. Шатилович, д. мед. н., професор кафедри акушерства та гінекології Львівського національного медичного університету ім. Данила Галицького, м. Львів

Акромегалія - рідкісне хронічне ендокринне захворювання, яке зазвичай викликається гіперсекрецією гормону росту (ГР) соматотрофною аденомою протягом тривалого періоду часу. Через фізіологічні зміни рівнів гіпофізарних гормонів, зв'язуючих глобулінів і плацентарних гормонів гормональна оцінка стає більш складною у вагітних жінок. Внаслідок фізіологічних гормональних змін оцінка функцій гіпофіза у вагітних жінок дуже відрізняється від такої у невагітних. Незважаючи на позитивний вплив сучасних методів лікування на виживання та якість життя, вагітність при акромегалії продовжує залишатися нечастою подією та проблемою для клініцистів. Діагностика акромегалії під час вагітності утруднена через зміни рівнів гіпофізарного ГР та інсуліноподібного фактора росту-1 (ІФР-1), вироблення ГР плацентою та нездатність рутинних методів відрізнити гіпофізарний ГР від плацентарного.

У більшості пацієнток з акромегалією вагітність не чинить несприятливого впливу на матір або ппід а маса гіпофіза не збільшуеться в розмірах. Збільшення пухлини теоретично може відбутися, якщо лікування, наприклад, аналогами соматостатину було припинено 3 настанням вагітності. Під час вагітності симптоми акромегалії зменшуються внаслідок збільшення синтезу естрогену, що інгібує вироблення IDP-1 в печінці. Перебіг вагітності здебільшого неускладнений, однак у літературі $є$ дані про підвищений ризик гестаційного діабету та гіпертензії в жінок із неконтрольованою до вагітності гіперсекрецією ГР/ІФР-1.

При збільшенні пухлини необхідним є частий моніторинг, хірургічне втручання може бути проведене у другому триместрі. Агоністи дофаміну та аналоги соматостатину можна застосовувати без шкідливих наслідків для матері чи плода. Під час вагітності медикаментозну терапію акромегалії слід відмінити та призначати лише при збільшенні пухлини та появі головного болю. Грудне вигодовування не впливає на перебіг акромегалії. У більшості випадків томографія гіпофіза не демонструє збільшення росту пухлини після вагітності.

Ключові слова: акромегалія, вагітність, гормон росту, інсуліноподібний фактор росту-1, агоністи дофаміну, аналоги соматостатину.

\section{ВЕДЕНИЕ БЕРЕМЕННОСТИ У ПАЦИЕНТОК С АКРОМЕГАЛИЕЙ}

\section{Обзор литературы}

Л.Б. Маркин, Д. мед. н., профессор, член-корреспондент НАМН Украины, заведующий кафедрой акушерства и гинекологии Львовского национального медицинского университета им. Данила Галицкого, г. Львов Е.Л. Шатилович, д. мед. н., профессор кафедры акушерства и гинекологии Львовского национального медицинского университета им. Данила Галицкого, г. Львов Акромегалия - редкое хроническое эндокринное заболевание, обычно вызываемое гиперсекрецией гормона роста (ГР) соматотрофной аденомой в течение длительного периода. Из-за физиологических изменений уровней гипофизарных гормонов, связывающих глобулинов и плацентарных гормонов, гормональная оценка становится более сложной у беременных женщин. Как следствие физиологических гормональных изменений оценка функций гипофиза у беременных женщин весьма отличается от оценки у небеременных. Несмотря на положительное влияние современных методов лечения на выживаемость и качество жизни, беременность при акромегалии продолжает оставаться редким явлением и проблемой для клиницистов. Диагностика акромегалии во время беременности затруднена из-за изменений уровней гормона роста (ГР) и инсулиноподобного фактора роста-1 (ИФР-1), выработки ГР плацентой и неспособности рутинных методов отличить гипофизарный ГР от плацентарного.

У большинства пациенток с акромегалией беременность не оказывает неблагоприятного воздействия на мать или плод, а масса гипофиза не увеличивается в размерах. Увеличение опухоли теоретически может произойти, если лечение, например, аналогами соматостатина было прекращено с наступлением беременности. Во время беременности симптомы акромегалии могут уменьшиться вследствие увеличения синтеза эстрогена, ингибирующего выработку ИФР-1 в печени. Беременность в основном протекает без осложнений, однако в литературе есть данные про повышенный риск гестационного диабета и гипертензии у женщин с неконтролируемой до беременности гиперсекрецией ГР/ИФР-1.

При увеличении опухоли необходим частый мониторинг, оперативное вмешательство может быть проведено во втором триместре. Агонисты дофамина и аналоги соматостатина могут быть использованы без каких либо неблагоприятных последствий для матери или плода. При беременности медикаментозную терапию акромегалии необходимо отменить и назначать только при росте опухоли и возникновении головной боли. Грудное вскармливание не влияет на течение акромегалии. В большинстве случаев томография гипофиза не демонстрирует увеличения роста опухоли после беременности.

Ключевые слова: акромегалия, беременность, гормон роста, инсулиноподобный фактор роста-1, агонисты дофамина, аналоги соматостатина. 